\title{
Pemurnian Fikosianin dari Spirulina platensis dengan Metode Liquid Biphasic Flotation (LBF) dan Penentuan Aktivitas Antioksidannya
}

\author{
Cori Yolanda Elise ${ }^{1}$, Marniati Salim ${ }^{1}$, Syafrizayanti ${ }^{*}$ \\ 1Jurusan Kimia, Fakultas Matematika dan Ilmu Pengetahuan Alam, Universitas Andalas, Sumatra \\ Barat, Indonesia
}

Corresponding Author:

Syafrizayanti

syafrizayanti@sci.unand.ac.id

Received: March 2021

Accepted: August 2021

Published: September 2021

CSyafrizayanti et al. This is an open-access article distributed under the terms of the Creative Commons Attribution License, which permits unrestricted use, distribution, and reproduction in any medium, provided the original author and source are credited.

\begin{abstract}
Phycocyanin from Spirulina platensis (S. Platensis) is a pigment-complex protein belong to the light-harvesting phycobiliprotein family. The pigments have high economic value as a natural blue dye as well as the source of antioxidants and anticancer. Production of pure natural phycocyanin remains in high demand. Therefore, this study aimed to obtain phycocyanin with high purity values using modified liquid biphasic flotation (LBF) system and tested for DPPH (1,1-diphenyl-2-pycrilhydrazil) radical scavenging activity. This study produced high purity phycocyanin with purification fold $3.041 \pm 0.04$ and recovery yields approximately about $70.881 \%$. Purified phycocyanin showed scavenging activity with IC 50 of $338.585 \mathrm{mg} / \mathrm{mL}$. Thus, the LBF system yielded high purity phycocyanin pigments.
\end{abstract}

Keywords: phycocyanin, Spirulina platensis, liquid biphasic flotation (LBF), $D P P H, I C$

\section{Pendahuluan}

Spirulina platensis (S. platensis) merupakan mikroalga sianobakteria yang telah diproduksi secara komersial sebagai antioksidan, pewarna alami dan suplemen makanan dalam industri farmasi. Salah satu pewarna alami yang terkandung pada $S$. platensis adalah pigmen fikosianin dengan perolehan sebanyak $18-20 \%$ dari total biomassa kering yang digunakan dalam proses ekstraksi ${ }^{[1]}$. Pigmen fikosianin dari mikroalga dapat dimurnikan melalui beberapa jenis metode pemurnian seperti metode kromatografi penukar ion, kromatografi filtrasi gel, dialysis, liquid biphasic system (LBS) dan masih banyak lagi. Namun pengunaan beberapa metode tersebut memiliki beberapa kelemahan seperti membutuhkan metode pengerjaan yang cukup memakan waktu, kurang efisien untuk diproduksi secara komersil dan membutuhkan biaya yang cukup tinggi[2]. Selain itu, pemurnian fikosianin dapat pula dilakukan menggunakan material kitosan dan arang aktif, material ini dilaporkan pernah digunakan pada sianobakteria laut Jaaginema sp. BTM-11. Pemurnian menggunakan material kitosan menghasilkan konsentrasi fikosianin sebesar $0.300 \mathrm{~g} / \mathrm{L}$ dan rasio kemurnian sebesar $1.42 \pm 0.04$ yang diukur menggunakan metode optical density (OD) sedangkan material arang aktif diperoleh konsentrasi $5.0 \mathrm{~g} / \mathrm{L}$ dengan rasio kemurnian sebesar $2.41 \pm 0.18$. Pemurnian fikosianin menggunakan kromatografi penukar ion paling umum dilakukan, pemurnian 
fikosianin dari $S$. platensis dengan metode kromatografi penukar ion menggunakan resin penukar ion Q-sepharose dilaporkan memperoleh rasio kemurnian sebesar $77.3 \%{ }^{[3]}$.

Berdasarkan nilai rujukan untuk penggunaan fikosianin, nilai kemurnian menggunakan material kitosan dan arang aktif masih rendah sehingga hanya bisa dimanfaatkan untuk pangan namun belum untuk bidang farmasi. Sedangkan dengan pemurnian menggunakan metode kromatografi penukar ion membutuhkan waktu pengerjaan yang lama dan tidak dapat diterapkan untuk pemurnian dalam skala besar. Hal ini disebabkan karena umumnya kolom yang digunakan relatif kecil dan pendek serta penggunaan resin yang cukup banyak ${ }^{[3]}$. Sedangkan pemurnian menggunakan sistem fasa dua cair yang dimodifikasi dengan tambahan flotasi udara (liquid biphasic flotation) dapat menutupi keterbatasan kromatografi penukar ion, dilaporkan dapat menghasilkan kemurnian sebesar 3.49 serta nilai recovery yield sebesar $81.2 \%$. Nilai kemurnian yang diperoleh menggunakan metode ini cukup tinggi dan memungkinkan pemanfaatan pigmen fikosianin semakin luas dalam skala yang lebih besar ${ }^{[4]}$.

Metode liquid biphasic flotation (LBF) adalah proses pemurnian molekul dengan gabungan sistem cair dua fasa dan flotasi gelembung udara. Gelembung tersebut akan berpindah dari fasa pelarut organik (fasa bawah) ke fase polimer (fasa atas). Metode pemisahan LBF dapat mengatasi keterbatasan pemurnian konvensional seperti tingkat kehilangan produk tinggi, tidak ekonomis, toxic, dan proses yang cukup panjang. Metode ini telah diterapkan dalam pemisahan berbagai biomolekul seperti pigmen, protein, lipase, bakteriosin, penisilin dan lain-lain ${ }^{[4]}$.

Pigmen fikosianin diketahui mengandung elemen fitonutrisi sebagai penangkal radikal bebas. Struktur pigmen fikosianin berupa molekul tetrapirol yang mampu meredam beberapa spesies oksigen reaktif dengan cara mendonorkan atom hidrogen ${ }^{[5]}$.

Kemampuan aktivitas antioksidan pigmen fikosianin setelah dilakukan pemurnian sudah pernah dilaporkan sebelumnya. Aktivitas antioksidan pigmen fikosianin menggunakan beberapa langkah pemurnian yaitu pengendapan dengan ammonium sulfat, dialisis, kromatografi filtrasi gel dan kromatografi penukar ion diperoleh nilai IC 50 sebesar $455.974 \mu \mathrm{g} / \mathrm{mL}$ sedangkan aktivitas antioksidan ekstrak kasar S. platensis diperoleh nilai IC $50846.660 \mu \mathrm{g} / \mathrm{mL}^{[6]}$, sehingga bioaktifitas pigmen fikosianin sebagai antioksidan menjadi lebih baik setelah dimurnikan, maka dari itu penelitian ini menggunakan metode pemurnian LBF untuk mendapatkan pigmen fikosiainin dengan rasio kemurnian dan recovery yield yang tinggi dan ditentukan kemampuan aktifitas antioksidanya.

\section{Metodologi Penelitian}

\section{Bahan kimia}

Bahan yang digunakan dalam penelitian ini yaitu biomassa Spirulina platensis yang diperoleh dari toko Fajar yang sudah bersertifikat Food and Drug Administration (FDA) United State (US), buffer fosfat $\mathrm{pH} 7\left(\mathrm{~K}_{2} \mathrm{HPO}_{4} \& \mathrm{KH}_{2} \mathrm{PO}_{4}\right)$ Merck, PEG 4000 g/L (Merck) dan $\mathrm{K}_{2} \mathrm{HPO}_{4} 250 \mathrm{~g} / \mathrm{L}$ (Merck), DPPH $0.1 \mathrm{mM}$ (Aldrich), metanol p.a (Merck), vitamin C (Merck), NuPAGE Bis-Tris Gels $4 \%$ stacking \& $12 \%$ running gel (Invitrogen), bolt LDS sample buffer (Invitrogen), bolt reducing agent (Invitrogen), bolt MES SDS running buffer (Invitrogen), commasie briliant blue (GBiosciences), asam asetat glasial (Fisher Scientific) dan akuades.

\section{Peralatan}

Alat-alat yang digunakan dalam penelitian ini adalah beberapa peralatan gelas, aluminum foil, autoklaf, timbangan analitik (Kern Abj), sentrifus (Health H-C-12 Centrifuge), pompa udara, corong filter kaca porositas Grade G4 (Quickfit), spektrofotometer UV-VIS (Thermo Scientific), gel cassette (Invitrogen), mini gel tank (Invitrogen), pipet mikro (Fraser), tips mikropipet 10 \& $1000 \mu \mathrm{L}$ (Kartell), vorteks (Wiggens), spin down, heating block (Corning), shaker (BJPX-103B), PowerEase power supply (Invitrogen), gel knife (Invitrogen). 


\section{Prosedur penelitian}

\section{Persiapan sampel}

Biomassa S. platensis yang diperoleh terlebih dahulu dilarutkan dengan akuades dan dilihat diatas cahaya miskroskop untuk memastikan apakah sel masih utuh atau sudah dilakukan tahap lisis. Jika sudah dilakukan tahap lisis maka S. platensis dapat dilanjutkan ketahap ekstraksi.

\section{Persiapan larutan buffer fosfat pH 7}

Pembuatan larutan buffer fosfat $\mathrm{pH} \quad 7$ menggunakan senyawa $\mathrm{K}_{2} \mathrm{HPO}_{4}$ dengan kosentrasi $0.41 \mathrm{M}$ dan $\mathrm{KH}_{2} \mathrm{PO}_{4} 0.086 \mathrm{M}$. Kedua senyawa tersebut dilarutkan hingga volumenya mencapai $1000 \mathrm{~mL}$ yang ditempatkan pada labu ukur 1000 mL dan dicek pH larutan.

\section{Ekstraksi biomassa Spirulina platensis}

Biomassa S. platensis seberat $10 \mathrm{~g}$ diekstrak dengan $250 \mathrm{~mL}$ larutan buffer fosfat $\mathrm{pH} \mathrm{7,}$ dilakukan pengadukan selama 15 menit hingga homogen. Campuran disentrifugasi 6,500 rpm selama 10 menit, ambil supernatan (ekstrak kasar) dan dikering anginkan selama 24 jam.

\section{Pemurnian pigmen fikosianin}

Supernatan dimurnikan dengan metode liquid biphasic flotation (LBF). Sebanyak $0.625 \mathrm{~g}$ ekstrak kering dilarutkan dengan $20 \mathrm{~mL} \quad \mathrm{~K}_{2} \mathrm{HPO}_{4}$. Campuran tersebut dimasukan pada corong filter kaca porositas Grade G4 dengan keadaan kran tertutup yang selanjutnya disebut sebagai fasa bawah. Kemudian ditambah $17 \mathrm{~mL}$ larutan PEG 4000 yang selanjutnya disebut sebagai fasa atas. Kran dibuka kemudian diberi aliran udara pada bagian bawah corong filter kaca porositas Grade G4 selama 7 menit. Selanjutnya, dilakukan pemisahan terhadap fasa atas dan fasa bawah dan dikeringkan pada suhu kamar. Ekstrak kering yang diperoleh disimpan pada suhu $4{ }^{\circ} \mathrm{C}$.

\section{Penentuan parameter hasil pemurnian pigmen fikosianin}

Pigmen fikosianin ditentukan hasil pemurniannya dengan menghitung nilai parameter hasil permurnian (Tabel 1). Parameter hasil pemurnian yang ditentukan yaitu nilai kosentrasi fikosianin (CPC), dan recovery yield $(\mathrm{RC})^{[4]}$. Penentuan parameter hasil pigmen fikosianin diawali dengan membuat larutan $0.2 \mathrm{mg}$ pigmen fikosianin dan dilarutkan dengan buffer fosfat $\mathrm{pH} 7$ sebanyak $0.01 \mathrm{~L}$ dan dihomogenkan.

\section{Visualisasi pigmen fikosianin hasil pemurnian dengan SDS-PAGE}

Pigmen fikosianin hasil pemurnian divisualisasikan dengan menggunakan Sodium Dodecyl Sulphate Poly Acrylamide Gel Electrophoresis (SDS-PAGE). SDS-PAGE mengunakan stacking gel dengan kosentrasi $4 \%$ dan running gel $12 \%$. Persiapan sampel untuk SDS-PAGE dimulai dengan denaturasi sampel, sebanyak $5 \mu \mathrm{L}$ sampel (ditambah $10 \mu \mathrm{L}$ bolt LDS sample buffer, $4 \mu \mathrm{L}$ bolt reducing agent dan $21 \mu \mathrm{L}$ air deionisasi) ditempatkan pada micro tube. Campuran divorteks selama 12 detik, spin down dan dipanaskan pada suhu $70{ }^{\circ} \mathrm{C}$ selama 10 menit. Kemudian dilanjutkan ke tahap running gel, NuPAGE Bis-Tris Gels dipasang pada gel cassette, tambah MOPS [3-(N-morpholino) propane sulfonic acid] SDS Running Buffer pada mini gel tank.

Tabel 1. Jenis parameter pemurnian fikosianin dan rumusnya

\begin{tabular}{lc}
\hline \multicolumn{1}{c}{ Parameter } & Rumus \\
\hline Kosentrasi Fikosianin (CPC) & $\mathrm{CPC}=\frac{\text { OD615-0.474 } \times \text { OD652 }}{5.34}$ \\
Recovery Yield (RC) & $\mathrm{RC}=\frac{\mathrm{K} \times \mathrm{Vr}}{1+\mathrm{K} \times \mathrm{Vr}}$ \\
\hline
\end{tabular}


Kemudian sebanyak $40 \mu \mathrm{L}$ marker protein dimasukkan ke dalam sumur pertama dan sebanyak $40 \mu \mathrm{L}$ sampel yang sudah direduksi diletakkan pada well berikutnya. Elektroforesis dijalankan pada tegangan 80 Volt $52 \mathrm{~mA}$ selama 70 menit atau hingga tracking dye mencapai ujung gel. Selanjutnya tahap staining, gel direndam dengan commasie briliant blue R-250 sebanyak $4 \mathrm{~mL}$ sambil dishaker selama 1 jam. Tahap destaining, gel direndam dengan campuran $25 \mathrm{~mL}$ metanol, $25 \mathrm{~mL}$ asam asetat glasial dan $200 \mathrm{~mL}$ akuades, dishaker selama 2 jam sampai muncul pita-pita berwarna biru dengan latar belakang jernih.

\section{Uji aktifitas antioksidan pigmen fikosianin dari S. platensis dengan metode DPPH}

Uji aktifitas antioksidan dilakukan dengan menggunakan metode DPPH. Kosentrasi DPPH yang digunakan yaitu $0.1 \mathrm{mM}$ dan larutan uji yang terdiri dari fasa atas (pigmen fikosianin), fasa bawah dan ekstrak kasar dengan variasi kosentrasi 800; 600; 400; 200 ;100; 50 dan 0 mg/L. Asam askorbat sebagai pembanding dengan variasi kosentrasi 8; 6; 4; 2 dan $0 \mathrm{mg} / \mathrm{L}$. Uji aktivitas antioksidan dilakukan dengan memipet $2 \mathrm{~mL}$ larutan uji dan ditambahkan 3 $\mathrm{mL}$ DPPH, dihomogenkan dan diinkubasi selama 30 menit. Absorban diukur pada panjang gelombang $517 \mathrm{~nm}$. Berdasarkan absorban yang didapatkan, dihitung persentase inhibisi dengan rumus berikut[7]:
$\%$ penangkapan radikal DPPH $=\frac{\mathrm{AK}-\mathrm{AS}}{\mathrm{AK}} \times 100 \%$

Keterangan:

$\mathrm{AK}=$ Absorban kontrol: metanol $+\mathrm{DPPH}$

AS = Absorban sampel: pigmen fikosianin + $\mathrm{DPPH}+$ methanol

\section{Hasil dan Diskusi}

\section{Ekstrak kasar fikosianin dari Spirulina platensis}

Ekstraksi biomassa kering S. platensis yang dilakukan menghasilkan rendemen yang cukup tinggi yaitu sebesar $36.25 \%$. Ekstrak memiliki ciri-ciri berwarna biru, berbentuk granula dan berbau menyengat (Gambar 1). Rendemen hasil ekstraksi yang tinggi menandakan bahwa pelarut yang digunakan dalam proses ekstraksi sesuai dengan sifat sampel. Kepolaran buffer fosfat $\mathrm{pH} 7$ yang yang digunakan sebagai pelarut ekstraksi cocok dengan pigmen fikosianin itu sendiri[ ${ }^{[7]}$.

Buffer fosfat $\mathrm{pH} 7$ sebagai pelarut untuk ekstraksi fikosianin dari S. platensis memiliki beberapa keunggulan. Buffer fosfat $\mathrm{pH} 7$ dapat menjaga kestabilan $\mathrm{pH}$ walaupun ditambahkan dengan sedikit asam maupun basa.

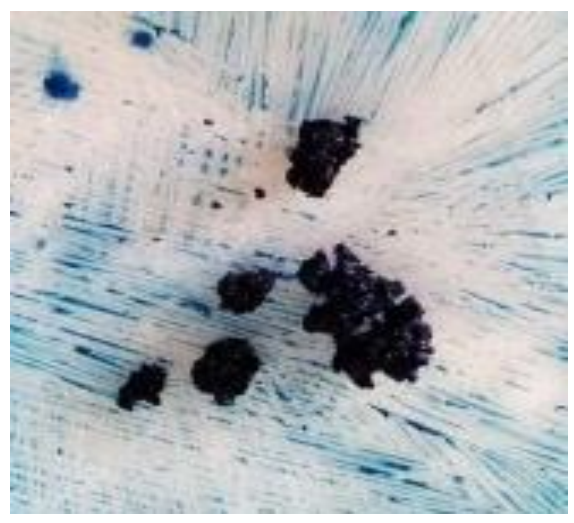

Gambar 1. Ekstrak kering Spirulina platensis. 
Kondisi ini cocok untuk sampel yang mudah mengalami kerusakan apabila terdapat perubahan $\mathrm{pH}$ yang ekstrim seperti pigmen fikosianin. Tingkat keasaman yang tetap dapat menjaga kondisi pigmen tetap stabil dari proses degradasi. Buffer juga memiliki nilai indeks kepolaran yang lebih tinggi yaitu 7.0 dibandingkan dengan air yang memiliki indeks kepolaran 6.8. Indeks kepolaran yang tinggi disebabkan karena nilai keelektronegatifan buffer fosfat yang tinggi dan memiliki sejumlah pasangan elektron bebas ${ }^{[8]}$.

Penggunaan buffer fosfat sebagai pelarut sering digunakan dalam kegiatan ekstraksi pada berbagai macam jenis sampel. Ekstraksi menggunakan pelarut buffer fosfat pernah dilaporkan diantaranya ekstraksi S. platensis diperoleh rendemen sebesar $20.22 \%{ }^{[9]}$, ekstraksi S. platensis menggunakan metode spray drying didapatkan rendemen sebesar $18.24 \%{ }^{[10]}$ dan ekstraksi S. fusiformis menggunakan pelarut buffer fosfat 30\% diperoleh rendemen sebesar $4.5 \mathrm{mg} / \mathrm{g}$. Penggunaan pelarut buffer fosfat sebagai pelarut berdasarkan penelitian yang pernah dilaporkan relatif menghasilkan rendemen yang cukup tinggi[8].

\section{Sistem LBF untuk pemurnian pigmen fikosianin}

Pigmen fikosianin diperoleh dari hasil pemurnian ekstrak kasar $S$. platensis menggunakan metode pemurnian liquid biphasic flotation (LBF). Penggunaan metode LBF bertujuan untuk membebaskan fikosianin yang berikatan silang (cross-linking) dengan protein. Metode LBF dikatakan efektif jika ikatan silang antara protein dan fikosianin terputus secara maksimal dan diikuti oleh partisi pigmen fikosianin pada fasa polimer, maka akan diperoleh pigmen fikosianin dengan nilai kemurnian dan recovery yield yang tinggi. Prinsip pemurnian LBF adalah salting-out dan flotasi gelembung udara pada dua fasa cair yang saling tidak bercampur ${ }^{[4]}$.

Liquid biphasic flotation (LBF) merupakan metode pemurnian efektif dan efisien untuk pemurnian pigmen fikosianin. LBF terdiri dari media dua fasa cair yang tidak saling bercampur yang terdiri dari fasa polimer dan fasa pelarut organik. Media dua fasa cair dapat disesuaikan dengan tujuan pemisahan dan sifat sampel. Pada penelitian ini media yang digunakan terdiri dari fasa atas dan fasa bawah (Gambar 2). Fasa atas merupakan larutan polietilenglikol 4000 (PEG) yang berfungsi sebagai medium perpindahan pigmen fikosianin dari fasa bawah. Fasa bawah menggunakan larutan $\mathrm{K}_{2} \mathrm{HPO}_{4}$ yang berfungsi menurunkan kelarutan protein. Penurunan kelarutan protein dapat dilakukan dengan cara menggunakan larutan garam dengan kosentrasi tinggi yang mengakibatkan molekul air akan berinteraksi dengan ion garam sehingga terjadi reaksi hidrofibik pada protein ${ }^{[4]}$.

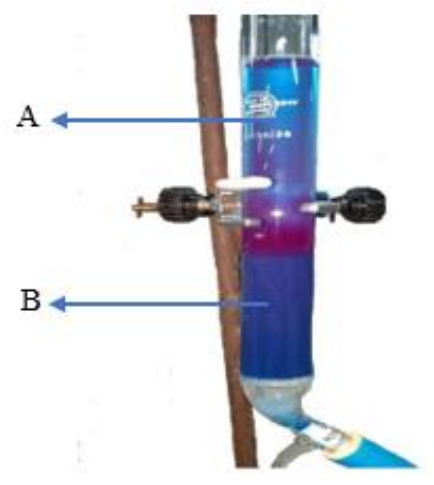

Gambar 2. Media dua fasa cair liquid biphasic flotation (LBF). Fasa atas (A) dan fasa bawah (B). 
PEG 4000 digunakan sebagai media perpindahan pigmen fikosianin. PEG 4000 merupakan polimer yang menfasilitasi perpindahan biomolekul pigmen fikosianin akibat proses transfer massa oleh flotasi gelembung udara. Penggunaan Polimer ini dalam pemurnian pigmen fikosianin dari $S$. platensis pernah dilaporkan mampu memberikan kemurnian dan nilai recovery yield yang tinggi yaitu 3.49 dan $81.2 \%{ }^{[4]}$. Apabila dibandingkan dengan penggunaan PEG yang memiliki berat molekul lebih kecil atau lebih besar dapat menghasilkan kemurnian atau nilai recovery yield yang rendah. Pemurnian menggunakan PEG dengan nilai kemurnian dan recovery yield rendah diakibatkan karena pori yang terlalu kecil menyebabkan kurang optimalnya pigmen fikosianin terpartisi pada medium PEG sedangkan ukuran pori yang terlalu besar akan mempengaruhi molekul selain pigmen fikosianin untuk ikut masuk pada medium perpindahan.

Larutan $\mathrm{K}_{2} \mathrm{HPO}_{4}$ merupakan pelarut organik yang digunakan sebagai fasa bawah. Penelitian ini menggunakan larutan $\mathrm{K}_{2} \mathrm{HPO}_{4}$ dengan kosentrasi $1.435 \mathrm{M}$. Larutan $\mathrm{K}_{2} \mathrm{HPO}_{4}$ dengan kosentrasi tinggi dapat menurunkan kelarutan protein. Penurunan kelarutan dapat terjadi akibat molekul air ditarik oleh ion-ion garam sehingga akan mengurangi interaksinya dengan protein. Keadaan ini mengakibatkan terjadinya interaksi hidrofobik antara sesama molekul protein sehingga menurunkan kelarutan dan mengendapkan protein yang berikatan dengan pigmen fikosianin ${ }^{[4]}$.

Pemurnian metode LBF mengunakan medium dua fasa cair memiliki banyak keuntungan. Penggunaan metode LBF dalam kegiatan pemurnian dapat mengatasi keterbatasan metode pemurnian konvensional seperti tingkat kehilangan produk tinggi, tidak ekonomis, toxic, proses yang cukup panjang dan pelarut yang dapat disesuaikan dengan sifat sampel[4].

\section{Parameter hasil pemurnian pigmen fikosianin}

Pigmen fikosianin setelah dilakukan pemurnian dihitung nilai kemurnian dan recovery yield untuk mengetahui efektifitas pemurnian serta tingkat kemurnian pigmen fikosianin yang diperoleh dicantumkan pada Gambar 3. Pigmen fikosianin dapat dimanfaatkan dalam berbagai sektor jika memiliki tingkat kemurnian tertentu. Kemurnian pigmen fikosianin yang dihasilkan pada penelitian ini adalah $3.041 \pm 0.04$. Kemurnian yang diperoleh cukup tinggi apabila dibandingkan dengan standar kemurnian pigmen fikosianin yaitu 0.7-4.0 dan beberapa kegiatan pemurnian fikosianin yang pernah dilakukan sebelumnya yaitu sianobakteria laut Jaginema sp. BTM-11 menggunakan material kitosan diperoleh rasio kemurnian sebesar 1.42 \pm 0.04 dan pemurnian dengan $5.0 \mathrm{~g} / \mathrm{L}$ arang aktif didapatkan kemurnian sebesar $2.41 \pm 0.18^{[11]}$.

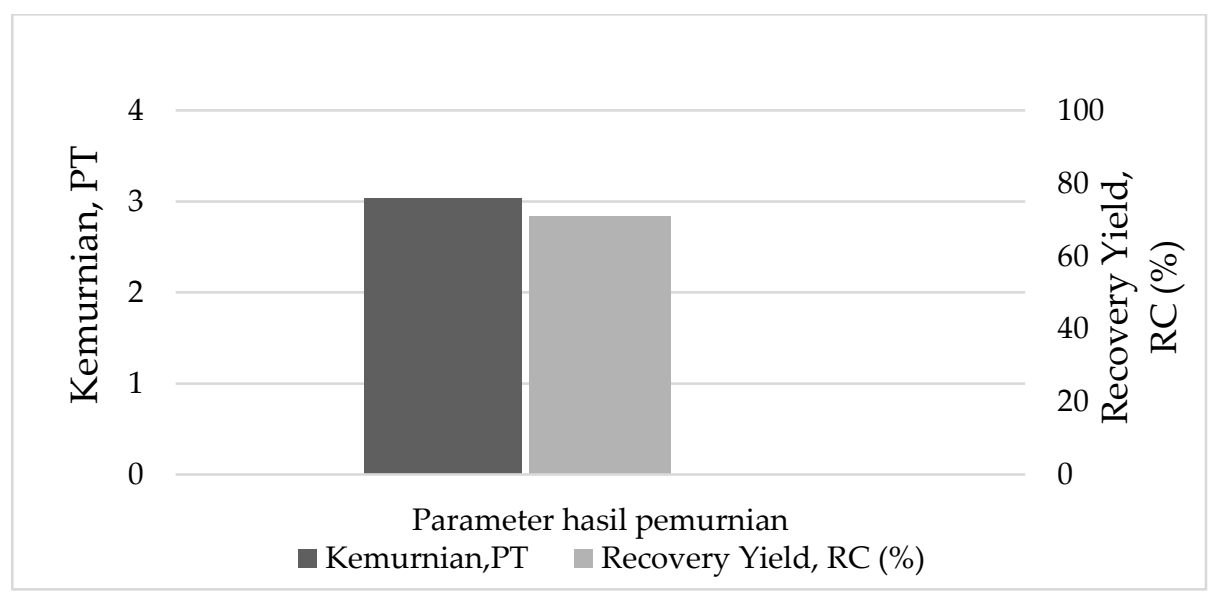

Gambar 3. Nilai parameter pemurnian dan recovery yield pigmen fikosianin. 
Nilai kemurnian pigmen fikosianin diperoleh berdasarkan hasil pengukuran terhadap perbandingan nilai absorban pigmen fikosianin pada $\lambda_{620} \mathrm{~nm}$ dan protein pada $\lambda_{280} \mathrm{~nm}^{[4]}$.

Nilai recovery yield pada pemurnian ini diperoleh sebesar $70.881 \%$. Proses partisi pigmen fikosianin dari fasa bawah ke fasa atas belum dilakukan secara maksimal. Hal ini disebabkan oleh beberapa faktor yaitu penggunaan air pump yang digunakan tidak memiliki pengatur laju udara sehingga flotasi gelembung udara yang dihasilkan tidak stabil. Lama waktu flotasi udara terlalu singkat yaitu 7 menit menyebabkan pigmen fikosianin pada fasa bawah belum terpartisi secara sempurna. Pigmen fikosianin pada penelitian ini dapat dimanfaatkan dalam bidang pangan dan kosmetik $^{[3]}$.

\section{Visualisasi pigmen fikosianin hasil pemurnian dengan SDS-PAGE}

Pigmen fikosianin hasil pemurnian divisualisasikan menggunakan metode Sodium Dodecyl Sulphate Poly Acrylamide Gel Electrophoresis (SDS-PAGE). SDS-PAGE bertujuan untuk mengetahui keberadaan pigmen fikosianin dengan melihat pita-pita yang terbentuk pada gel. Tahap denaturasi sampel dapat membantu pigmen fikosianin yang berikatan dengan protein terpisah sehingga pita pigmen fikosianin dapat terbaca pada gel akrilamid walaupun ukuran biomolekulnya kecil[6].

Pita pigmen fikosianin ditemukan pada gel poliakrilamid dengan range $14-28 \mathrm{kDa}$. Pita ini ditemukan pada sumur fasa atas, fasa bawah dan ekstrak kasar (Gambar 4).

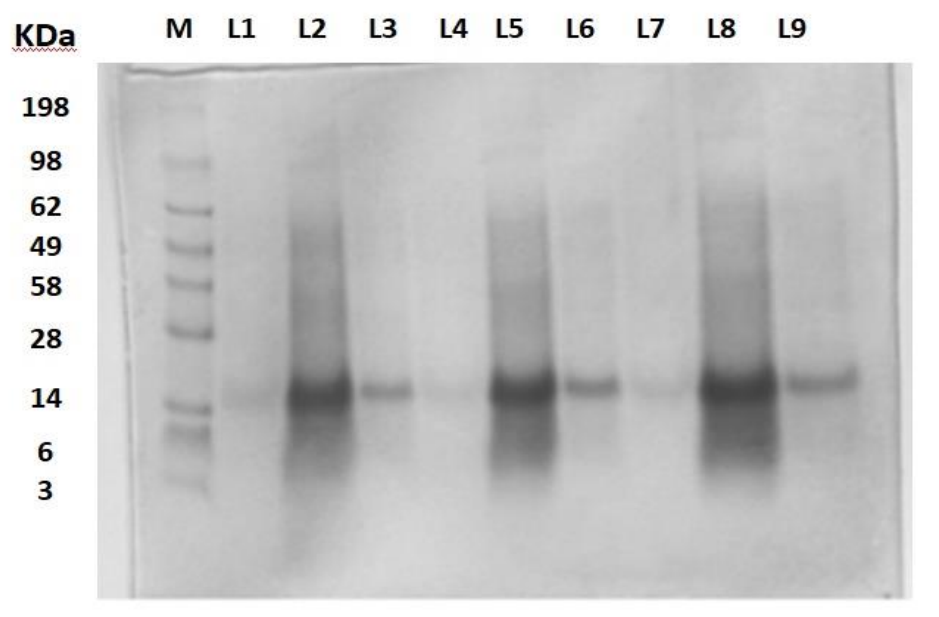

Gambar 4. Visualisasi pigmen fikosianin hasil pemurnian dengan SDS-PAGE. Posisi pigmen fikosianin ditandai pada pita dalam lingkaran merah.

Keterangan gambar:

\begin{tabular}{ll}
\hline M: Maker & L5: Fasa bawah 2 \\
L1: Fasa Atas 1 & L6: Ekstrak kasar 2 \\
L2: Fasa bawah 1 & L7: Fasa Atas 3 \\
L3: Ekstrak kasar 1 & L8: Fasa bawah 3 \\
L4: Fasa Atas 2 & L9: Ekstrak kasar 3 \\
\hline
\end{tabular}


Sumur fasa atas yang merupakan hasil pemurnian terdapat 1 pita yang muncul yaitu pigmen fikosianin (14-28 kDa). Apabila dibandingkan dengan sumur fasa bawah dan ekstrak kasar terdapat pita protein dan pita pigmen fikosianin. Pita protein yang muncul cukup tebal pada bagian sumur fasa bawah akibat terjadinya proses salting-out pada protein ${ }^{[4]}$. Sumur fasa bawah terdapat pita pigmen fikosianin hal ini membuktikan bahwa pigmen fikosianin belum maksimal terpartisi pada fasa atas. ${ }^{7}$ ISumur ekstrak kasar merupakan sumur dengan sampel tanpa dilakukan pemurnian jika dibandingkan dengan sumur fasa atas terlihat perbedaan terhadap jumlah dan ketebalan pita, hal ini menunjukan bahwa pemurnian pigmen fikosianin menggunakan metode LBF dapat memutuskan ikatan antara pigmen fikosianin dengan protein ${ }^{[4]}$.

\section{Aktifitas antioksidan pigmen fikosianin dari S. platensis dengan metode DPPH}

Uji aktivitas antioksidan dilakukan untuk melihat bioaktifitas pigmen fikosianin dari fasa atas, sisa pigmen fikosianin difasa bawah dan pigmen fikosianin yang ada pada ekstrak kasar. Pengujian aktivitas antioksidan dilakukan menggunakan metode DPPH. Metode DPPH merupakan metode yang sesuai untuk uji aktivitas antioksidan pigmen fikosianin karena didasari pada struktur pigmen fikosianin yang memiliki elektron bebas untuk meredam radikal DPPH. Prinsip peredaman radikal bebas DPPH berdasarkan transfer atom $\mathrm{H}$ dari senyawa antioksidan untuk menetralkan DPPH yang ditandai dengan penurunan intensitas warna larutan DPPH dari warna ungu menjadi kuning[5].

Nilai kosentrasi yang mampu menangkap 50\% radikal DPPH diplotkan terhadap ekstrak kasar, fasa atas dan fasa bawah (Gambar 5). Hasil uji aktivitas antioksidan pada masing-masing sampel yang terdiri-dari ekstrak kasar menghasilkan nilai IC 50 sebesar $411.368 \mathrm{mg} / \mathrm{mL}$, fasa bawah sebesar $1158.59 \mathrm{mg} / \mathrm{mL}$ dan fasa atas (pigmen fikosianin) sebesar $338.585 \mathrm{mg} / \mathrm{mL}$. Uji aktivitas antioksidan pigmen fikosianin hasil pemurnian yang diperoleh pada penelitian ini memberikan nilai $\mathrm{IC}_{50}>150 \mathrm{mg} / \mathrm{mL}$ sehingga pigmen fikosianin dari S.platensis tergolong antioksidan lemah walaupun sudah dilakukan proses pemurnian[12]. Apabila dibandingkan dengan pigmen lain yang juga terdapat pada $S$. platensis seperti pigmen karotenoid dilaporkan memiliki nilai $\mathrm{IC}_{50}$ sebesar $1444.50 \mathrm{mg} / \mathrm{mL}^{[13]}$, bisa dibandingkan bahwasanya kemampuan pigmen fikosianin sebagai antioksidan lebih baik dibandingkan karotenoid.

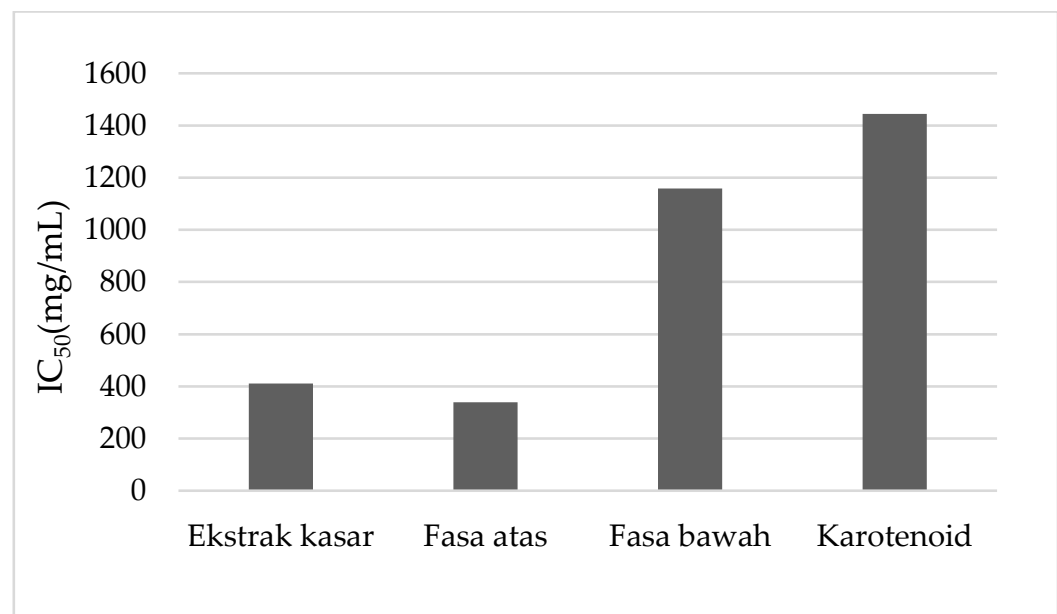

Gambar 5. Nilai IC 50 untuk menangkal radikal DPPH dari ekstrak kasar, fasa atas (pigmen fikosianin), fasa bawah dan pigmen karotenoid sebagai pembanding. 
Hal ini diperkuat dengan beberapa hasil penelitian terkait aktivitas antioksidan pigmen fikosianin dari Spirulina.sp menggunakan pelarut akuades dengan perolehan nilai $\mathrm{IC}_{50}$ $110.80 \mu \mathrm{g} / \mathrm{mL}^{[14]}$ dan dengan pelarut buffer fosfar $\mathrm{pH} 7186.76 \mu \mathrm{g} / \mathrm{mL}^{[14]}$. Pada fasa bawah tidak menunjukan aktivitas antioksidan yang baik karena pigmen fikosianin sebagian besar sudah terpartisi pada fasa atas sedangkan ekstrak kasar memberikan nilai IC $_{50}>150$ $\mathrm{mg} / \mathrm{mL}$ tergolong antioksidan lemah ${ }^{[12]}$. Perolehan nilai IC 50 pada ekstrak kasar karena mengandung pigmen-pigmen lainya seperti allo-fikosianin, fikoeritrin dalam kosentrasi kecil dan senyawa metabolit sekunder polar lainya yang mampu memberikan efek antioksidan seperti flavonoid.

\section{Kesimpulan}

Pigmen fikosianin yang diperoleh dari hasil pemurnian dengan metode liquid biphasic flotation (LBF) dari S. platensis didapatkan kemurnian yang cukup tinggi yaitu $3.041 \pm 0.04$ dengan recovery yield sebesar $70.881 \%$ dapat disimpulkan bahwa metode ini sangat baik digunakan untuk pemurnian pigmen fikosianin. Pigmen fikosianin dengan tingkat kemurnian tersebut mampu menangkal $50 \%$ radikal DPPH pada konsentrasi $338.585 \mathrm{mg} / \mathrm{mL}$.

\section{Ucapan Terima Kasih}

Penulis mengucapkan terima kasih kepada Laboratorium Biokimia Fakultas Matematika dan Ilmu Pengetahuan Alam (FMIPA) Universitas Andalas dan Laboratorium Biomedik Fakultas Kedokteran Universitas Andalas yang telah memfasilitasi penulis dalam melakukan kegiatan selama penelitian.

\section{Daftar Pustaka}

1. Fakhri, M., Antika, P. W., Ekawati, A. W. \& Arifin, N. B., Growth, pigment and protein production of Spirulina platensis under different $\mathrm{Ca}(\mathrm{NO} 3) 2$ concentrations. J. Aquac. Fish Heal., 9(1): 38-47 (2020).

2. Figueira, F. da S., Moraes, C. C. \& Kalil, S.
J., C-phycocyanin purification: multiple processes for different applications. Brazilian J. Chem. Eng., 35(3): 1117-1128 (2018).

3. Patil, G., Chethana, S., Sridevi, A. S. \& Raghavarao, K. S. M. S., Method to obtain C-phycocyanin of high purity. J. Chromatogr. A, 1127(1-2): 76-81 (2006).

4. Chew, K. W., Chia, S. R., Krishnamoorthy, R., Tao, Y., Chu, D. T. \& Show, P. L., Liquid biphasic flotation for the purification of $\mathrm{C}$ phycocyanin from Spirulina platensis microalga. Bioresour. Technol., 288: 1-30 (2019).

5. Stocker, R., Glazer, A. N. \& Ames, B. N., Antioxidant activity of albumin-bound bilirubin. Proc. Natl. Acad. Sci., 84(16): 59185922 (1987).

6. Oktaviani, E. A., Potensi fikosianin Spirulina platensis hasil purifikasi bertahap sebagai antioksidan dan inhibitor enzim kolagenase. Universitas Sriwijaya, (2017).

7. Rahmawati, S. I., Hidayatulloh, S. \& Suprayatmi, M., Ekstraksi fikosianin dari Spirulina plantesis sebagai biopigmen dan antioksidan. J. Pertan., 8(1): 36-45 (2017).

8. Firdayani, F., Agustini, T. W. \& Ma'ruf, W. F., Ekstraksi senyawa bioaktif sebagai antioksidan alami Spirulina platensis segar dengan pelarut yang berbeda. J. Pengolah. Has. Perikan. Indones., 18(1): 28-37 (2015).

9. Wulandari, D. A., Setyaningsih, I. \& Asih, P. B. S., Ekstraksi dan aktivitas antimalaria fikosianin dari Spirulina platensis secara in vitro. J. Pengolah. Has. Perikan. Indones., 19(1): 17-25 (2016).

10. Astuti, W. M., Dewi, E. N. \& Kurniasih, R. A., Pengaruh perbedaan jenis pelarut dan suhu pemanasan selama ekstraksi terhadap stabilitas mikrokapsul fikosianin dari Spirulina platensis. J. Ilmu dan Teknol. Perikan., 1(1): 7-14 (2019).

11. Praharyawan, S., Setyaningsih, T., Susilaningsih, D. \& Siregar, Y. D. I., Peningkatan kemurnian dan toksisitas ekstrak pigmen C-fikosianin dari sianobakteria laut Jaaginema sp. BTM-11 dengan menggunakan kitosan dan arang 
aktif. J. Pascapanen dan Bioteknol. Kelaut. dan Perikan., 14(1): 21-28 (2019).

12. Taylor, S. \& Todd, P. A., Understanding information technology usage: A test of competing models. Inf. Syst. Res., 6(2): 144176 (1995).

13. Agustina, M. D., Kandungan pigmen fikosianin dan karotenoid Spirulina platensis yang dikultivasi menggunakan warna lampu berbeda. IPB University, (2019).

14. Ridlo, A., Sedjati, S. \& Supriyantini, E., Aktivitas anti oksidan fikosianin dari Spirulina Sp. menggunakan metode transfer elektron dengan DPPH (1, 1difenil-2-pikrilhidrazil). J. Kelaut. Trop., 18(2): 58-63 (2016). 